Практическая значимость. Предложенная технология может быть использована для очистки внутренней полости шлейфов низконапорных газовых и газоконденсатных скважин и промышленных газопроводов от скоплений жидкости. В результате обеспечивается стабильная работа скважины с повышенными дебитами газа и конденсата.

\section{UDC 622.281 .74}

R. M. Tereshchuk, Cand. Sc. (Tech.), Assoc. Prof., orcid.org/0000-0003-4509-2511,

N. V. Khoziaikina, Cand. Sc. (Tech.), Assoc. Prof., orcid.org/ 0000-0002-4747-3913,

D. V. Babets, Cand. Sc. (Tech.), Assoc. Prof., orcid.org/ 0000-0002-5486-9268
Ключевые слова: очистное устройство, вязкоупругий поршень, поверхностно-активное вещество, газопровод, скважина

Рекомендовано до публікації докт. техн. наук I.I. Чудиком. Дата надходження рукопису 12.10.16.

\title{
SUBSTANTIATION OF RATIONAL ROOF-BOLTING PARAMETERS
}

Р. М. Терещук, канд. техн. наук, доц., orcid.org/0000-0003-4509-2511, Н. В. Хозяйкіна, канд. техн. наук, доц., orcid.org/ 0000-0002-4747-3919, Д. В. Бабець, канд. техн. наук, доц., orcid.org/ 0000-0002-5486-9268
DOI: $10.29202 /$ nvngu/2018-1/18

National Mining University, Dnipro, Ukraine, e-mail: tereschuk. rm@gmail.com

\section{ОБГРУНТУВАННЯ РАЦІОНАЛЬНИХ ПАРАМЕТРІВ АНКЕРНИХ СИСТЕМ}

Purpose. To analyse a state of border rock mass of permanent slope mine working in the process of roof-bolting mounting. To determine rational roof-bolting density as well as length of anchors in the deepening process in the context of $m_{4}^{2}$ seam of Pioner mine ("DTEK Dobropolliavuhillia" Ltd).

Methodology. Roof-bolting parameters for the permanent slope mine workings were substantiated while analysing regularities of changes in behaviour and stress-strain state of rock mass and identifying displacements of rock contour of a mine working. Thereupon, rational values of anchor lengths and roof-bolting density based upon them were determined. To analyse changes in the behaviour and stress-strain state of border rock mass of permanent inclined mine working with roof-bolting, a finite-element method was applied.

Findings. A method to analyse both behaviour and stress-strain state of border rock mass of permanent inclined mine workings in the context of roof-bolting mounting has been substantiated. The procedure of the problem solution while using developed software has been described. Calculation model to solve a problem concerning the determination of rational roof-bolting density and anchor lengths to support permanent inclined mine workings in the context of their depth changes has been developed. Rational parameters of roof-bolting while supporting permanent inclined mine workings under specific mining and geological conditions have been determined.

Originality. Graphs of dependences of roof rock border displacements and floor of permanent inclined mine working on its depth in terms of anchor length and roof-bolting density have been obtained.

Practical value. Results of the studies may be used at the design stage to forecast displacements of a roof, a floor and walls of permanent inclined mine workings under the conditions of $m_{4}^{2}$ seam at Pioner mine to optimize roofbolting parameters.

Keywords: inclined mine working, mathematical modelling, roof bolting, mine

Introduction. Over recent years mining depth of coal deposits has experienced significant deepening; moreover, mining and geological conditions have deteriorated. Maintenance of permanent mine workings in such a situation being the essential condition of safe underground operations as well as sustainability of high technical-andeconomic indices of coal-mining enterprises involves con-

(C) Tereshchuk R. M., Khoziaikina N.V., Babets D. V., 2018 siderable expenses connected with repair-and-renewal operations.

As a rule, Ukrainian mines use metallic arched flexible supports made of special shape to reinforce both permanent and development underground mine workings. Arched three-link support is the most popular among all support types. However, the available metallic arched flexible supports prevent permanent inclined mine workings from keeping them in operating conditions during the 
whole working period especially in a zone affected by mining operations.

The problem can be solved partially at the initial stage of the mine working construction using possibilities of rock mass itself; we mean the increase in its bearing capability being implemented by means of "basic supportrock mass-additional measures" system. The latter is possible with the use of methods of protection aimed at the inclusion of border rock mass in combined action with protective structures. Roof bolting is one of the support types implementing the idea. In this context, its basic task involves the correct selection of its parameters: mounting density and anchor length.

Analysis of the recent research. Analysis of research studying support systems, protection, and means to improve their stability, helps conclude that arched metallic flexible supports in deep mine workings cannot resist rock pressure to the full; thus, it is not expedient to deal with the formation of zones of non-elastic deformation by means of increasing the bearing capability of the support [1].

The performed analysis of available ideas concerning interaction between roof bolting and border rock mass [2], methods of roof-bolting used in mine workings to control their stability with the help of rock roof-bolting preserving the rock mass in the state of triaxial compression and forming a high-strength structure of rock roof bolting [3] as well as methods to determine support parameters has shown that despite the variety of the studies carried out and their great number [4], the effect of rock roof-bolting structures on geomechanical processes taking place within rock mass enclosing the mine working is understudied.

Papers [5-8] carried out considerable volume of research to study parameters of roof-bolting systems mounted in nonhomogeneous border rock mass of inclined mine workings under mining and geological conditions of 'DTEK Dobropolliavuhillia' ltd mines. Regularities of changes in stress-strain state of anchored roof rocks [5] and walls [6] of mounting manway in terms of different support parameters to provide their stability have been analysed to obtain dependences of roof and floor displacements of inclined mine working if the length and number of anchors mounted within border rock mass vary. Moreover, rational roof-bolting parameters for $m_{5}^{16}$ and $m_{4}^{0}$ seams of 'Dobropilska' mine ('DTEK Dobropolliavuhillia' ltd) have been determined [7].

Unsolved aspects of the problem. Several hypotheses concerning the studies of anchored border rock mass operation mode are worth mentioning.

The hypothesis by B.K. Chukan, A.P.Shirokov, I. A. Yurchenko and other authors applied in the context of minor dimensions of caving zone is as follows: anchors resist falling rocks hanging them up to the more stable upper rock mass. In this context, both length and the number of roof bolting depend upon parameters of natural arch, exfoliations, inrushes, unstable border layer, a zone of non-elastic deformations, and bearing capability of anchor or bolted anchor clamp.

The hypothesis by G. Sena, E. Thomas, O.Jacobi, A. A. Borisov and other authors is as follows: mounting of roof bolting into border rock mass forms load-carrying structure. However, determination of rock roof-bolting parameters on the basis of the hypothesis in the context of deep depths involves certain difficulties and reliability of the obtained results decreases.

According to the following hypothesis, roof bolting is the means to improve the stability of border rock mass of mine workings. It is efficient to be mounted in stable rocks, in unstable rocks even if roof-bolting length is shorter than the dimensions of non-elastic deformation zone.

However, the available methods, techniques, and approaches to substantiate roof-bolting parameters (analytical, graphical, energetical, etc.) based upon the abovementioned hypotheses gives no way for the complete solution of the problem concerning determination of roofbolting parameters for permanent inclined mine workings in the context of different mining and geological conditions [9].

Even normative sources relating to the use of roof bolting in mine workings cannot provide a decisive answer as for the parameters of roof bolting under complicated and very complicated mining and geological conditions [8].

Objectives of the article. It is required to analyse a state of border rock mass of permanent inclined mine working while roof bolting mounting with the use of mathematical modelling methods. Results of the analysis will be a basis for determination of rational roof-bolting density as well as anchor length in terms of deepening depth under mining and geological conditions of $m_{4}^{2}$ seam of a mine 'Pioner' ('DTEK Dobropilliavuhillia' ltd).

Presentation of the main research. Parameters of roofbolting systems for permanent inclined mine workings were substantiated in the process of studies of regularities concerning the changes in behaviour and stress-strain state (SSS) of rock mass and detection of displacements of rock border of a mine working. The abovementioned was used to identify rational values of anchor length and roof-bolting density.

To study changes in behaviour and stress-strain state of border rock mass of permanent inclined mine working with roof bolting, finite-element method (FEM) was used which has already been sufficiently tested and may be applied in different spheres. To compare with all the mathematical methods engaged in the studies of rock mass, the finite-element method makes it possible to consider mechanical processes in a wide range and forecast both qualitative and quantitative results of rock pressure manifestations in mine workings.

While studying with the help of FEM, area is divided into variform components (triangular, quadrangular, etc.). The components are related in nodes. Transfers inside each component are described by means of certain functions. Then, stiffness matrix relating loads and transfers inside the nodes is formed for each component. Finally, global stiffness matrix and global load vector are formed for the whole area under study.

One of the most successful packages to study stressstrain state of roof-bolted border rock mass has been applied in the process of the analysis. We mean software SW (CGGM) developed by employees of the Department of Construction, Geotechnics and Geomechanics. 
The problem solving assumed the form of repeated recurring actions for the determination of components in which the condition $\sigma_{e}>R_{c}$ was met $\sigma_{e}>R_{c}\left(R_{c}\right.$ is ultimate compression strength, and $\sigma_{e}$ stands for equivalent stresses). In his papers, A. N. Shashenko has proposed a ratio to determine $\sigma_{e}$. The ratio takes into consideration both maximum and minimum primary stresses [10].

Initially, border rock mass is assumed as completely elastic. Its physical and mechanical parameters are introduced, and SW (CGGM) is used to solve linear static problem and to determine SSS. Then, with the help of data concerning stress-strain state of the rock mass, boundaries of non-elastic deformations are determined at the first stage of the solving.

After that, special-purpose SW (CGGM) program is used to vary initial parameters of the problem (components for which $\sigma_{e}>R_{c}$ solutions were obtained, i.e. material within the components transit from elastic phase into non-elastic one) for the further solution at stage two.

Then the solution procedure repeats. If it is required, elasticity module and Poisson's coefficient vary. Linear problems are solved with the system stiffness matrix compiled on the basis of secant modules.

Solution stage two as well as the following ones uses nonlinear SW (CGGM) module. If at a certain solution stage has no components meeting $\sigma_{e}>R_{c}$ condition, then the process of inelasticity zone determination is considered to be completed.

Since SSS of nonlinear medium depends heavily on the method of finite load application, then to obtain correct collusion in the calculations, systematic loading was applied.

First, a part of design load was applied to the area under study; a linear problem was solved and stresses within components as well as node transitions were determined. Then, the next load part was applied and solution was performed. Stresses within components and nodes transition are summed up. The paper adopts 10 steps of the load application.

Mathematical model of the interaction between roof bolting systems and rock mass was implemented by means of elasto-plastic problem solution.
While studying, FEM was applied to model mining and geological conditions of a manway of seam $m_{4}^{2}$ inclination of $500 \mathrm{~m}$ level in Pioner mine. Mining operations were performed with the help of КСП-32 coal shearer. Arched flexible support АП-15.5 was applied. Clear opening is $15.5 \mathrm{~m}^{2}$. A type of the applied plates is reinforced-concrete one for the roof and wooden one for the walls. A pitch of the support mounting is $800 \mathrm{~mm}$. The mine working location to the dip is 14 degrees.

Physical and mathematical parameters of coal seam and enclosing rocks involving the results obtained in paper [11] were used in the process of mathematical modelling of roof bolting system of permanent inclined mine workings. Table 1 demonstrates the results.

Objectives of the studies were to determine rational density of roof bolting and anchor length depending upon the depth of the mine working. The following parameters varied in the process of numerical modelling: anchor density $-N_{a}=3 . .9$ pieces, anchor lengths $-l_{a}=2.2 \ldots .5 \mathrm{~m}$ and depth of the mine working $-H=700 \ldots 1500 \mathrm{~m}$.

Roof bolting within the rock mass was modelled as follows. First, a problem of mining operations with no support was solved and radial transfers within nodes of the components were determined. Next, no vertical and horizontal transfers being longer than the transfers at the end of roof bolting were allowed along the whole length of the roof bolting within coinciding nodes of anchor components and rock mass. Radial transfers within the roofbolting area were assumed as constant ones, i.e. no more than $2 \%$ deformations were permitted.

Fig. 1 demonstrates the calculation scheme to solve the problem of rational roof-bolting density and anchor length to support permanent inclined mine workings while changing mine working depth.

Fig. 2 visualizes the results of mathematical modelling of permanent inclined mine working while roof-bolting systems mounting.

Results of permanent inclined mine working mathematical modelling in the context of mining and geological conditions of $m_{4}^{2}$ seam at Pioner mine with roof bolting in the context of the varied roof-bolting param-

Table 1

Physical and mechanical parameters of coal rock mass

\begin{tabular}{|l|c|c|c|c|c|c|}
\hline \multicolumn{1}{|c|}{ Material } & $\begin{array}{c}\text { Elasticity } \\
\text { module, } \\
10^{4} \mathrm{MPa}\end{array}$ & $\begin{array}{c}\text { Poisson's } \\
\text { ratio }\end{array}$ & $\begin{array}{c}\text { One-axis ultimate } \\
\text { compression } \\
\text { strength, MPa }\end{array}$ & $\begin{array}{c}\text { Ultimate tensile } \\
\text { strength, } \\
\mathrm{MPa}\end{array}$ & $\begin{array}{c}\text { Rock } \\
\text { density, } \\
\mathrm{t} / \mathrm{m}^{3}\end{array}$ & $\begin{array}{c}\text { Seam } \\
\text { thickness, } \\
\mathrm{m}\end{array}$ \\
\hline $\begin{array}{l}\text { Argillite } \\
\text { (main roof) }\end{array}$ & 0.8 & 0.23 & 30 & 3.0 & 2.4 & 15.0 \\
\hline $\begin{array}{l}\text { Aleurolite } \\
\text { (immediate roof) }\end{array}$ & 1.0 & 0.22 & 40 & 4.0 & 2.5 & 4.0 \\
\hline Coal seam $m_{4}^{2}$ & 0.9 & 0.16 & 15 & 1.5 & 1.6 & 1.2 \\
\hline $\begin{array}{l}\text { Aleurolite } \\
\text { (immediate roof) }\end{array}$ & 1.0 & 0.22 & 40 & 4.0 & 2.4 & 4.0 \\
\hline $\begin{array}{l}\text { Sandstone } \\
\text { (main floor) }\end{array}$ & 1.65 & 0.21 & 50 & 5.0 & 2.5 & 20.0 \\
\hline
\end{tabular}




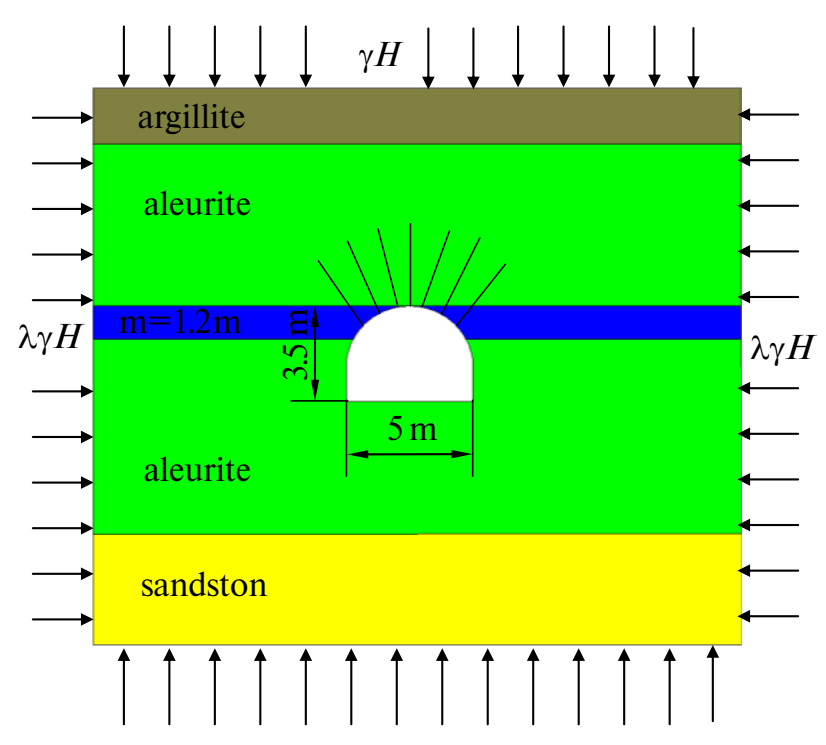

Fig. 1. Calculation scheme to solve a problem concerning substantiation of roof-bolting parameters for permanent inclined mine workings

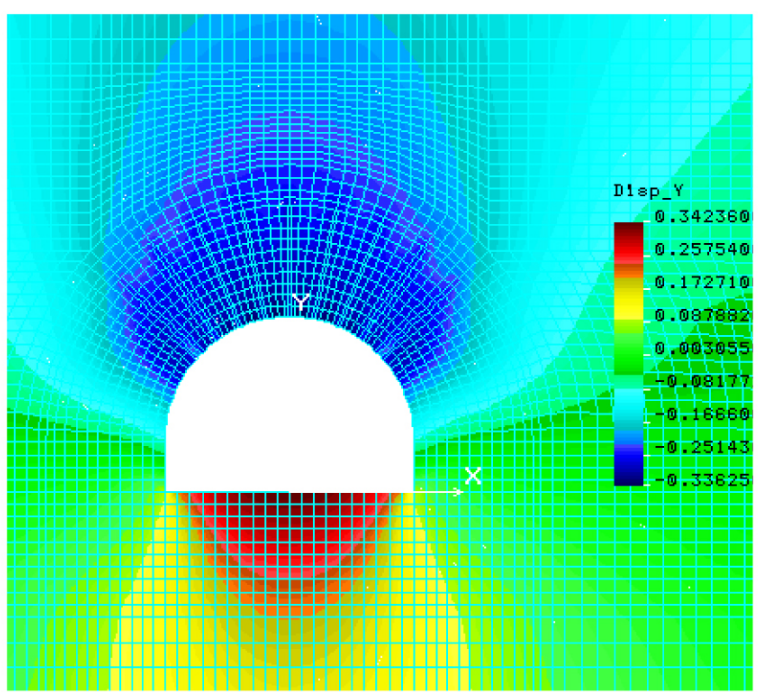

$a$ eters $\left(N_{a}=3 \ldots 9\right.$ pieces $)$ and $\left(l_{a}=2.2 \ldots 3.5 \mathrm{~m}\right)$ as well as the depth $(H=700 \ldots 1500 \mathrm{~m})$ are represented in the form of the dependences of border rock mass displacements (mine working roof and floor). The paper involves graphs of dependences of the mine working roof and floor displacements: on its depth while using anchors with 2.2 and $3 \mathrm{~m}$ lengths (Figs. 3 and 4), on roof-bolting density if depth of the mine working is 700 and $1500 \mathrm{~m}$ (Figs. 5 and 6), on anchor lengths, if depth of the mine working is 700 and $1500 \mathrm{~m}$ (Figs. 7 and 8).

Analysis of the obtained results.

1. Results of mathematical modelling and full-scale studies (performed as a part of self-financing R\&D No. 050131-01/4-213, 2012) show that difference in roof and floor displacements of inclined mine is 5 and $2 \%$ respectively. Hence, it is possible to state that the mathematical model developed in this paper is adequate.

2. Dependences of changes in roof and floor displacements of permanent inclined mine working with roof bolting for each alternative for anchor mounting being studied in the context of its depth deepening can be described with the help of equations of $u_{i}=a_{1} H_{i}+a_{2}$ form (Figs. 3

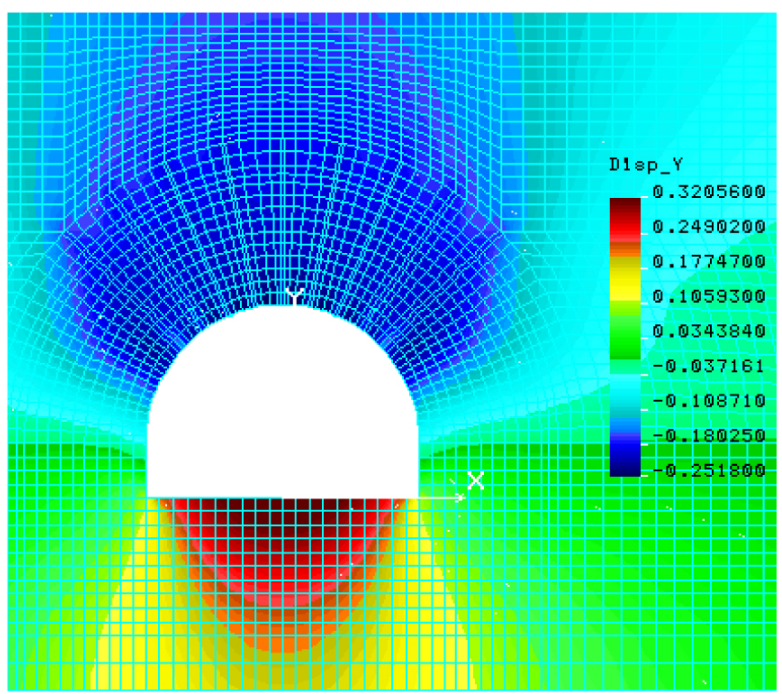

$b$

Fig. 2. General view of border rock mass transitions when the mine working is supported with the help of nine roof bolts at the depth of $1500 \mathrm{~m}(a-l a=2.2 \mathrm{~m} ; b-l a=3.0 \mathrm{~m})$

$u_{r}, \mathrm{~mm}$

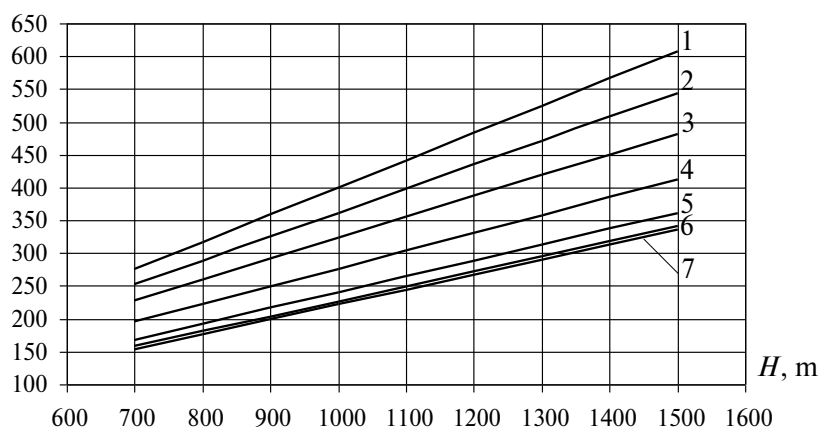

$a$ $u_{r}, \mathrm{~mm}$

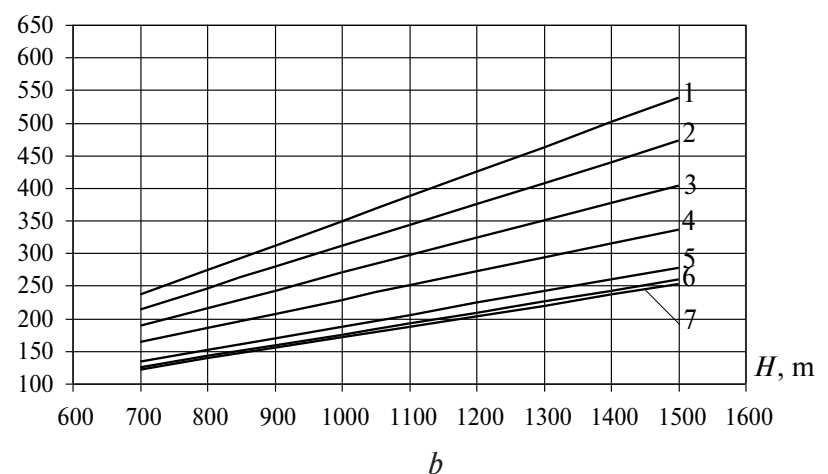

$b$

Fig. 3. Graphs of dependences of roof displacement value changes on the mine working depth, if anchor lengths are: $a-2.2 m ; b-3 m$ (1-3 anch.; $2-4$ anch.; $3-5$ anch.; $4-6$ anch.; $5-7$ anch.; $6-8$ anch.; $7-9$ anch.) 


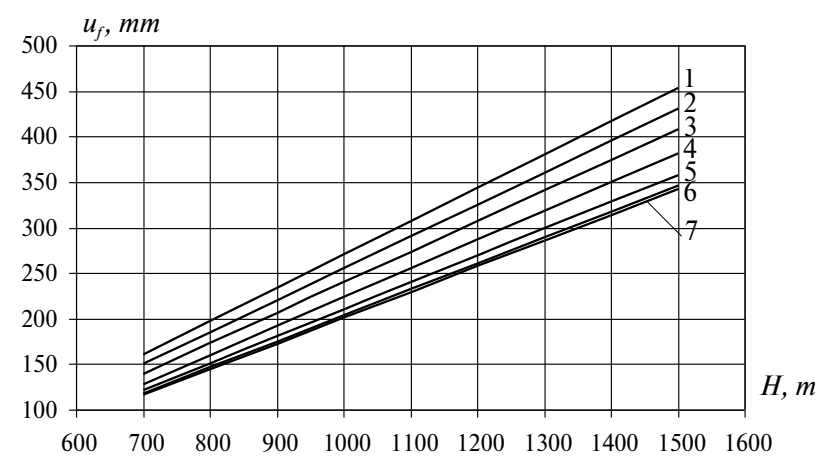

$a$

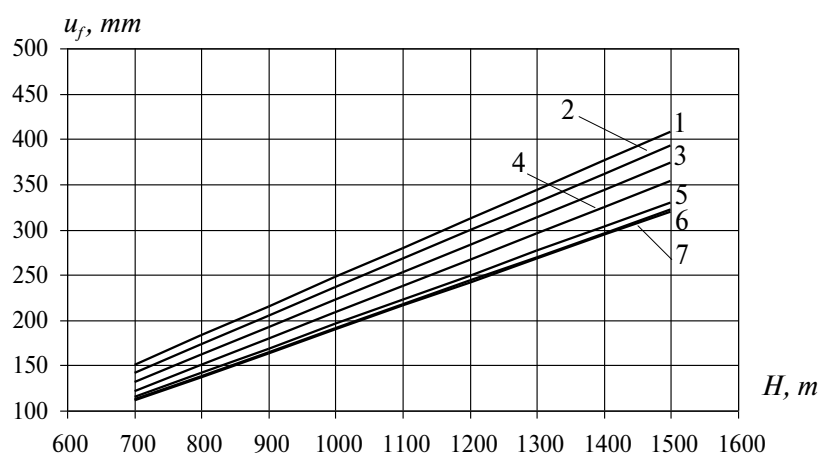

$b$

Fig. 4. Graphs of dependences of floor displacement value changes on the mine working depth, if anchor lengths are: $a-2.2 m ; b-3 m$ (1 - 3 anch.; $2-4$ anch.; $3-5$ anch.; $4-6$ anch.; $5-7$ anch.; 6 - 8 anch.; 7 - 9 anch.)
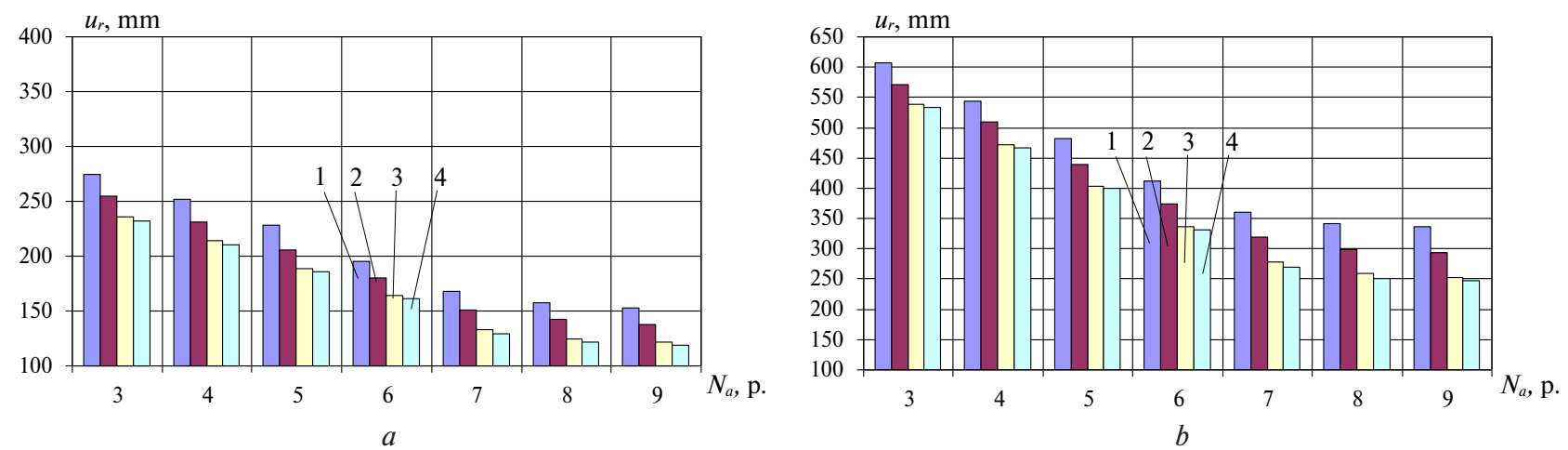

Fig. 5. Graphs of dependences of roof displacement value changes on the roof-bolting density, if mine working depths are: $a-700 \mathrm{~m} ; b-1500 \mathrm{~m}\left(1-l_{a}=2.2 \mathrm{~m} ; 2-l_{a}=2.5 \mathrm{~m} ; 3-l_{a}=3.0 \mathrm{~m} ; 4-l_{a}=3.5 \mathrm{~m}\right)$
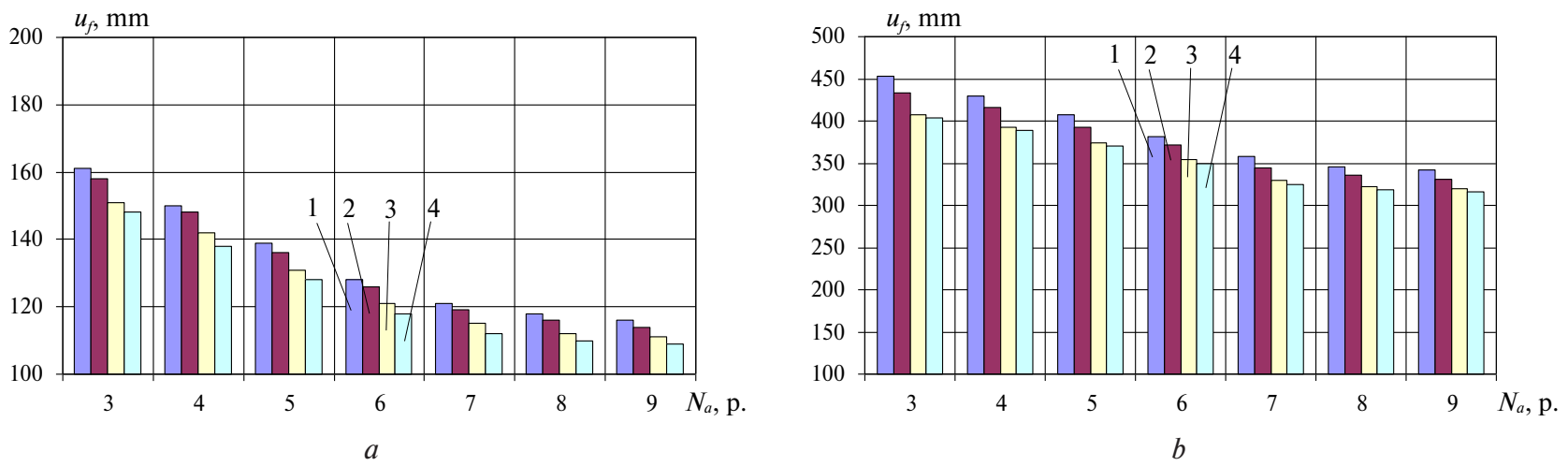

Fig. 6. Graphs of dependences of floor displacement value changes on the roof-bolting density, if mine working depths are: $a-700 \mathrm{~m} ; b-1500 \mathrm{~m}\left(1-l_{a}=2.2 \mathrm{~m} ; 2-l_{a}=2.5 \mathrm{~m} ; 3-l_{a}=3.0 \mathrm{~m} ; 4-l_{a}=3.5 \mathrm{~m}\right)$

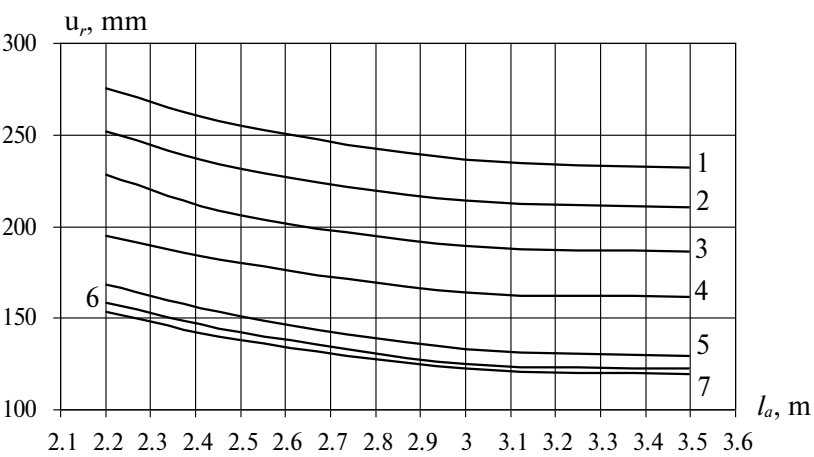

$a$

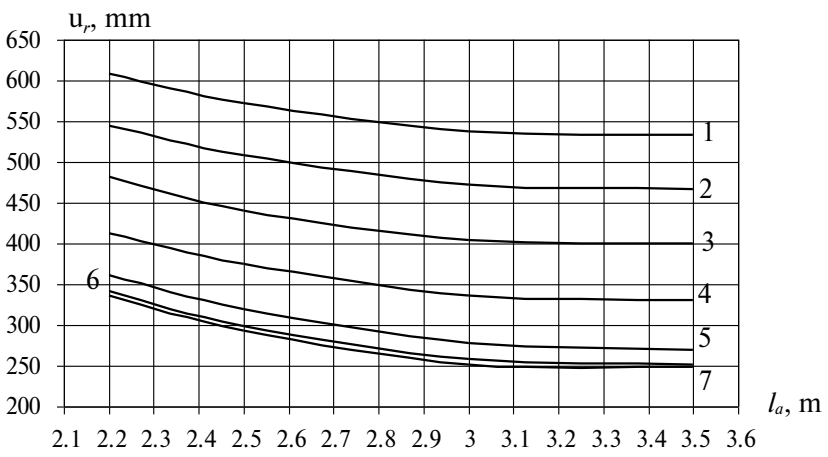

$b$

Fig. 7. Graphs of dependences of roof displacement value changes on anchor length, if mine working depths are: $a-700$ m; $b-1500 m$ (1-3 anch.; $2-4$ anch.; $3-5$ anch.; $4-6$ anch.; $5-7$ anch.; $6-8$ anch.; $7-9$ anch.) 


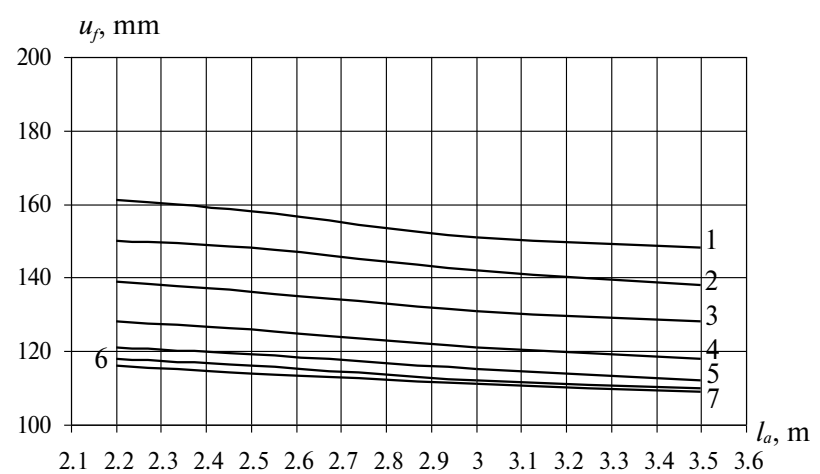

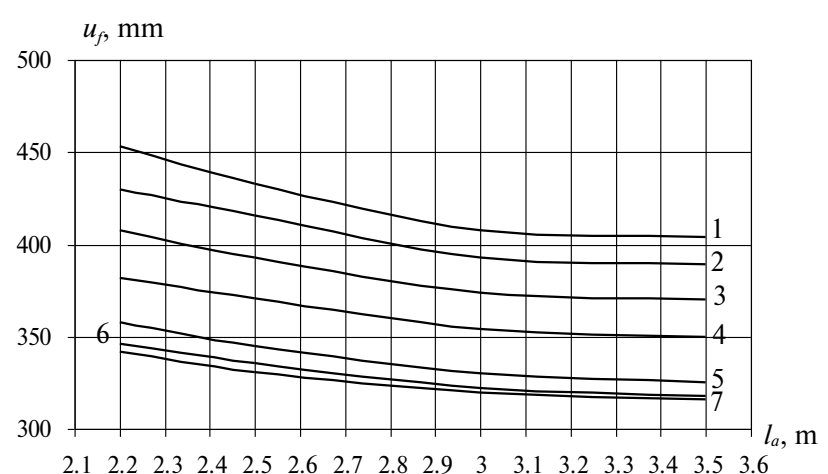

Fig. 8. Graphs of dependences of floor displacement value changes on anchor length, if mine working depths are: $a-700$ m; $b-1500 m$ (1-3 anch.; $2-4$ anch.; $3-5$ anch.; $4-6$ anch.; $5-7$ anch.; $6-8$ anch.; 7 - 9 anch.)

and 4). Table 2 contains values of equation $a_{1}$ and $a_{2}$ for a case when the length of the mounted anchors is $3 \mathrm{~m}$ and the depth of the mine depth varies from $700 \mathrm{~m}$ down to $1500 \mathrm{~m}$.

3. The value of changes in roof displacements in the context of mine working deepening and use of anchors with 2.2 and $3 \mathrm{~m}$ length respectively is: for 3 anchors -42 and $38 \mathrm{~mm}$ per $100 \mathrm{~m}$; for 9 anchors -23 and $16 \mathrm{~mm}$ per $100 \mathrm{~m}$ (Fig. 3).

4. The value of changes in floor displacements in the context of mine working deepening and use of anchors with 2.2 and $3 \mathrm{~m}$ length respectively is: for 3 anchors 37 and $32 \mathrm{~mm}$ per $100 \mathrm{~m}$; for 9 anchors -28 and $26 \mathrm{~mm}$ per $100 \mathrm{~m}$ (Fig. 4).

5 . In the context of mine working deepening, the difference between roof displacements (when roof bolting is performed with the help of 3 to 9 anchors) increases when the length of the anchors is $2.2 \mathrm{~m}$ and $3 \mathrm{~m}$ respectively being: 122 and $114 \mathrm{~mm}$ at the depth of $700 \mathrm{~m}$, and 272 and $286 \mathrm{~mm}$ at the depth of $1500 \mathrm{~m}$ (Fig. 5).

6 . The value of roof displacements decreases if the number of anchors varies ( 3 to 9$)(H=700 \mathrm{~m})$ being described by means of the polynomial dependence:

- if $l_{a}=2.2 \mathrm{~m}$, then

$u_{r}=0.8889 N_{a}^{3}-8.619 N_{a}^{2}-1.8651 N_{a}+284.43$;

- if $l_{a}=3 \mathrm{~m}$, then

$u_{r}=0.8889 N_{a}^{3}-8.6905 N_{a}^{2}+0.2063 N_{a}+239$.

7. The value of roof displacements decreases if the number of anchors varies ( 3 to 9$)(H=1500 \mathrm{~m})$ being described by means of the polynomial dependence:

- if $l_{a}=2.2 \mathrm{~m}$, then

$$
\begin{aligned}
& u_{r}=1.4444 N_{a}^{3}-10.869 N_{a}^{2}-40.456 N_{a}+658 ; \\
& - \text { if } l_{a}=3 \mathrm{~m} \text {, then } \\
& u_{r}=1.6944 N_{a}^{3}-13.536 N_{a}^{2}-35.516 N_{a}+580.14 .
\end{aligned}
$$

8 . In the context of mine working deepening, the difference between floor displacements (if 3 to 9 anchors are applied) increases if anchor length is 2.2 and $3 \mathrm{~m}$ respectively being 45 and $40 \mathrm{~mm}$ at the depth of $700 \mathrm{~m}$; and 11 and $88 \mathrm{~mm}$ at the depth of $1500 \mathrm{~m}$ (Fig. 6).

9. The value of floor displacements decreases if the number of anchors varies ( 3 to 9$)(H=700 \mathrm{~m})$ being described by means of the polynomial dependence:

- if $l_{a}=2.2 \mathrm{~m}$, then

$u_{f}=0.1389 N_{a}^{3}-0.5595 N_{a}^{2}-10.913 N_{a}+172.57$;

- if $l_{a}=3 \mathrm{~m}$, then

$u_{f}=0.1389 N_{a}{ }^{3}-0.5595 N_{a}{ }^{3}-9.9127 N_{a}+158.57$.

10. The value of a roof displacements decreases if the number of anchors varies (3 to 9) $(H=1500 \mathrm{~m})$ being described by means of the polynomial dependence:

- if $l_{a}=2.2 \mathrm{~m}$, then

$u_{f}=0.6389 N_{a}^{3}-5.8929 N_{a}^{2}-7.6746 N_{a}+465,43$;

- if $l_{a}=3 \mathrm{~m}$, then

$u_{f}=0.7778 N_{a}^{3}-7.9643 N_{a}^{2}+4.8294 N_{a}+406$.

11. In the context of mine working deepening, difference between roof displacements (if anchors with 2.2 ... $3.5 \mathrm{~m}$ are used) increases if the number of anchors is 3 and 9 pieces respectively being: 43 and $34 \mathrm{~mm}$ at the depth of $700 \mathrm{~m}$; and 75 and $88 \mathrm{~mm}$ at the depth of $1500 \mathrm{~m}$ (Fig. 7).

12. The value of a roof decreases if the length of anchors varies within $2.2 \ldots 3.5 \mathrm{~m}(H=700 \mathrm{~m})$ being described by means of the polynomial dependence:

Table 2

Coefficients of equation $a_{1}$ and $a_{2}$

\begin{tabular}{|c|c|c|c|c|c|c|c|}
\hline $\begin{array}{c}\text { The number } \\
\text { of anchors, } \\
\text { pieces }\end{array}$ & 3 & 4 & 5 & 6 & 7 & 8 & 9 \\
\hline \multicolumn{8}{|c|}{ Roof } \\
\hline$a_{1}$ & 0.3775 & 0.3225 & 0.2688 & 0.215 & 0.1813 & 0.1675 & 0.1625 \\
\hline$a_{2}$ & -28.25 & -11.75 & 0.875 & 13.5 & 6.125 & 7.75 & 8.25 \\
\hline \multicolumn{8}{|c|}{ Floor } \\
\hline$a_{1}$ & 0.3213 & 0.3138 & 0.3038 & 0.2913 & 0.2688 & 0.2625 & 0.2613 \\
\hline$a_{2}$ & -73.875 & -77.625 & -81.625 & -82.875 & -73.125 & -71.75 & -71.875 \\
\hline
\end{tabular}


- if $N_{a}=3$ pieces, then

$u_{r}=31.99 l_{a}^{2}-215.22 l_{a}+593.48$;

- if $N_{a}=9$ pieces, then

$u_{r}=24.806 l_{a}^{2}-167.67 l_{a}+401.91$.

13. The value of a roof displacements decreases if the length of anchors varies within 2.2 ...3.5 m $(H=1500 \mathrm{~m})$ being described by means of the polynomial dependence:

- if $N_{a}=3$ pieces, then

$u_{r}=60.388 l_{a}{ }^{2}-401.67 l_{a}+1199.2$;

- if $N_{a}=9$ pieces, then

$u_{r}=74.91 l_{a}^{2}-494.59 l_{a}+1061.4$.

14. In the context of mine working deepening, the difference between floor displacements (if anchors with $2.2 \ldots 3.5 \mathrm{~m}$ are used) increases if the number of anchors is 3 and 9 pieces respectively being: 13 and $7 \mathrm{~mm}$ at the depth of $700 \mathrm{~m}$; and 49 and $26 \mathrm{~mm}$ at the depth of $1500 \mathrm{~m}$ (Fig. 8).

15. The value of a floor displacements decreases if the length of anchors varies within 2.2...3.5 m $(H=750 \mathrm{~m})$ being described by means of the polynomial dependence:

- if $N_{a}=3$ pieces, then

$u_{f}=10 l_{a}{ }^{3}-82 l_{a}{ }^{2}+209.5 l_{a}-9.5$;

- if $N_{a}=9$ pieces, then

$u_{f}=0.8974 l_{a}{ }^{3}-6.0769 l_{a}{ }^{2}+7.0064 l_{a}+120.44$.

16. The value of floor displacements decreases if the length of anchors varies within 2.2...3.5 $\mathrm{m}(H=1500 \mathrm{~m})$ being described by means of the polynomial dependence:

- if $N_{a}=3$ pieces, then

$u_{f}=34.778 l_{a}{ }^{2}-236.65 l_{a}+805.94$;

- if $N_{a}=9$ pieces, then

$u_{f}=15.479 l_{a}^{2}-108.08 l_{a}+504.73$.

17. Under the mining and geological conditions of $m_{4}^{2}$ seam at Pioner mine, the rational length of anchors mounted within a mine working roof is almost $3.0 \ldots 3.1 \mathrm{~m}$, and density is $0.83 \ldots 0.71 \mathrm{anch} / \mathrm{m}^{2}\left(N_{a}=6-7\right.$ pieces $)$; roofbolting of permanent inclined mine workings is meant.

18. Dependences of floor and roof displacements in permanent inclined mine working on its depth $(700 \ldots$ $1500 \mathrm{~m}$ ) if the number of anchors (3...9 pieces) and their lengths $(2.2 \ldots 3.5 \mathrm{~m})$ vary, may be used to forecast displacement while designing a manway for inclination of $m_{4}^{2}$ seam of $500 \mathrm{~m}$ level at Pioner mine during its deepening as well as in the context of similar mining and geological conditions for mine workings being under construction. For instance, if the depth is 1100 and $3 \mathrm{~m}$ anchors are used, then expected roof displacements should be $250 \mathrm{~mm}$. Fig. 3 explains that in the context of the conditions it required to use 6 anchors; if so, floor displacements will be $237 \mathrm{~mm}$ (Fig. 4, $b$ ).

Fig. 9 demonstrates that mounting of roof bolting will result in the decrease in relative displacements by $\Delta U$ value within the mine working border; in turn, that will factor into $\Delta \omega$ value increase in the stability of the mine working. It is possible to determine economic efficiency of roof bolting relying upon that.

Conclusions and recommendations for further research. In the context of mining and geological conditions of $m_{4}^{2}$ seam at Pioner mine, dependences of roof and floor of permanent inclined mine working on the depth of its location have been analysed while varying roof-bolting density

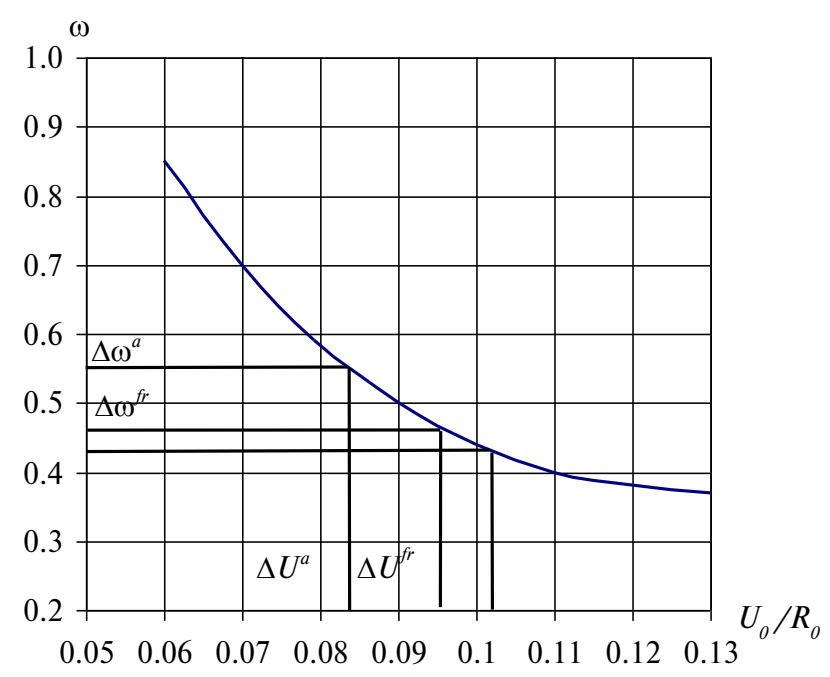

Fig. 9. Dependence of a mine working stability index $\omega$ on relative displacements of the mine working border $U_{0} / R_{0}\left(U_{0}\right.$ are radial displacements of the border, $R_{0}$ is radius of the mine working)

and lengths of anchors. It is possible to use the obtained dependences to forecast displacements of border rock mass while designing inclined mine workings in the context of $m_{4}^{2}$ seam of Pioner mine as well as under similar conditions for inclined mine workings being constructed. That will help make reasonable selection of roof bolting and frame-and-roof bolt support while developing standards to construct and support mine workings.

Further studies will be focused on the substantiation of technologically and economically sound parameters of roof-bolting systems for permanent inclined mine workings under different mining and geological conditions of "DTEK Dobropilliavuhillia" ltd.

\section{References.}

1. Bulat, A. F., 2014. Advanced technologies for tunnel supporting in Ukrainian coal mines. Visnyk of the $\mathrm{Na}$ tional Academy of Sciences of Ukraine, 1, pp. 74-79.

2. Bulat, A. F., Popovich, I. M., Vivcharenko, J. V. and Krukovskiy, O.P., 2014. Technology of bolting of mine workings at mines in Ukraine: state and prospects, Ugol Ukrainy, 2, pp. 3-7.

3. Krukovskiy, A.P., Khvorostian, V.A. and Krukovskaia, V.V., 2013. Technology of supporting bolting of mine workings. Ugol Ukrainy, 2, pp. 13-16.

4. Krukovskiy, A. P., 2014. Technology of supporting bolting of mine workings of coal mines. Zb. prac im. D. A. Kunaeva Nauchno-tekhnicheskoe obespechenie gornogo proizvodstva, 86, pp. 26-33.

5. Novikov, A. O. and Gladkiy, S. YU., 2015. Mathematical model of deformation state of roof rock in working, tip by anchors, Zb. nauk. prac Geo-Technikal Mechanics, 119, pp. 205-220.

6. Novikov, A. O. and Gladkiy, S. YU., 2015. Mathematical model of deformation state of rock wall in working, tip by anchors. In: Annual scientific-technical collection Mining of mineral deposits 2015, pp. 319-325.

7. Tereschuk, R. and Tereschuk, O., 2014. Determination of rational parameters for roof bolting of inclined work- 
ings. Up-to-date resource- and energy-saving technologies in mining industry. Research and production journal: Kremenchuk Mykhailo Ostrohradskyi National University, 2(14), pp. 104-113.

8. Ministry of Energy and Coal Mining of Ukraine, 2014. SOU 10.1.05411357.010:2014. System of providing reliable and safe functioning of roof-bolting mine workings. General technical requirements. Kyiv: Minenerhovuhillia Ukrainy.

9. Pivnyak, G., Dychkovskyi, R., Smirnov, A. and Cherednichenko, Y., 2013. Some aspects on the software simulation implementation in thin coal seams mining. Energy Efficiency Improvement of Geotechnical Systems, pp. 1-10. DOI: $10.1201 / \mathrm{b} 16355-2$.

10. Shashenko, O. M. and Kovrov, O. S., 2016, Comparative analysis of two failure criteria for rocks and massifs. Naukovyi Visnyk Natsionalnoho Hirnychoho Universytetu, 6, pp. 54-59.

11. Babets, D. V., Sdvyzhkova, O.O., Larionov, M.H. and Tereshchuk, R. M., 2017. Estimation of rock mass stability based on probability approach and rating systems, Naukovyi Visnyk Natsionalnoho Hirnychoho Universytetu, 2, pp. 58-64.

Мета. Дослідження стану приконтурного породного масиву капітальної похилої гірничої виробки при встановленні анкерних систем. Визначення раціональної щільності анкерування й довжини анкерних штанг при збільшенні глибини ії̈ закладення в умовах пласта $m_{4}^{2}$ шахти „Піонер“ ТОВ „ДТЕК Добропіллявугілля“.

Методика. Обгрунтування параметрів анкерних систем для капітальних похилих виробок виконувалося шляхом дослідження закономірностей зміни поведінки й напружено-деформованого стану породного масиву та отримання зміщень породного контуру гірничої виробки. На цій основі проведено визначення раціональних величин довжини анкерних штанг і щільності анкерування. Для досліджень змін поведінки й напружено-деформованого стану приконтурного породного масиву капітальної похилої виробки, що закріплена анкерними системами, використовувався метод скінченних елементів.

Результати. Обгрунтовано спосіб дослідження поведінки й напружено-деформованого стану приконтурного породного масиву капітальної похилої виробки при встановленні анкерних систем. Описана процедура вирішення задачі з використанням розробленого програмного продукту. Розроблена розрахункова схема для вирішення задачі визначення раціональної щільності анкерування й довжини анкерів для кріплення похилих виробок при зміні глибини їх закладення. Визначені раціональні параметри анкерних систем при кріпленні капітальних похилих гірничих виробок у конкретних гірничо-геологічним умовах.

Наукова новизна. Отримані графіки залежностей зміщень породного контуру покрівлі й підошви капітальної похилої виробки від глибини її розміщення при варіюванні довжини анкерних штанг і щільності анкетування.
Практична значимість. Результати досліджень можуть бути використані на стадії проектування для прогнозу зміщень покрівлі, підошви й боків капітальних похилих виробок у гірничо-геологічних умовах пласта $m_{4}^{2}$ шахти „Піонер“ для оптимізації параметрів анкерних систем.

Ключові слова: похила виробка, математичне моделювання, анкерне кріплення, шахта

Цель. Исследование состояния приконтурного породного массива капитальной наклонной выработки при установке анкерных систем. Определение рациональной плотности анкерования и длины анкерных штанг при увеличении глубины ее заложения в условиях пласта $m_{4}^{2}$ шахты „Пионер“ ООО „ДТЭК Добропольеуголь“.

Методика. Обоснование параметров анкерных систем для капитальных наклонных выработок осуществлялось путем исследования закономерностей изменения поведения и напряженно-деформированного состояния породного массива и нахождения смещений породного контура горной выработки. На этой основе проведено определение рациональных величин длины анкерных штанг и плотности анкерования. Для исследования изменений поведения и напряженно-деформированного состояния приконтурного породного массива капитальной наклонной выработки, закрепленной анкерными системами, применялся метод конечных элементов.

Результаты. Обоснован способ исследования поведения и напряженно-деформированного состояния приконтурного породного массива капитальной наклонной выработки при установке анкерных систем. Описана процедура решения задачи с использованием разработанного программного продукта. Разработана расчетная схема для решения задачи определения рациональной плотности анкерования и длины анкеров для крепления капитальных наклонных выработок при изменении глубины их заложения. Определены рациональные параметры анкерных систем при креплении капитальных наклонных горных выработок в конкретных горногеологических условиях.

Научная новизна. Получены графики зависимостей смещений породного контура кровли и почвы капитальной наклонной выработки от глубины ее расположения при варьировании длины анкерных штанг и плотности анкерования.

Практическая значимость. Результаты исследований могут быть использованы на стадии проектирования для прогноза смещений кровли, почвы и боков капитальных наклонных выработок в горно-геологических условиях пласта $m_{4}^{2}$ шахты „Пионер” для оптимизации параметров анкерных систем.

Ключевые слова: наклонная выработка, математическое моделирование, анкерная крепь, шахта

Рекомендовано до публікації докт. техн. наук А.М. Роєнком. Дата надходження рукопису 07.12.16. 